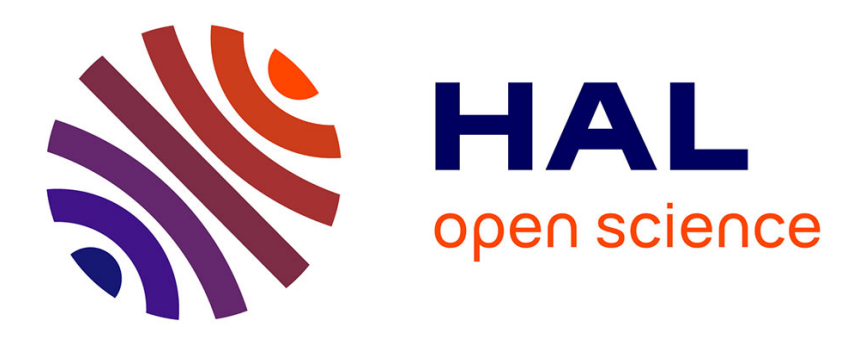

\title{
Informalising Readmission Agreements in the EU Neighbourhood
}

\author{
Jean-Pierre Cassarino
}

\section{To cite this version:}

Jean-Pierre Cassarino. Informalising Readmission Agreements in the EU Neighbourhood. The International Spectator, 2007, 42 (2), pp.179-196. 10.1080/03932720701406365 . hal-01232695

\section{HAL Id: hal-01232695 \\ https://hal.science/hal-01232695}

Submitted on 25 Nov 2015

HAL is a multi-disciplinary open access archive for the deposit and dissemination of scientific research documents, whether they are published or not. The documents may come from teaching and research institutions in France or abroad, or from public or private research centers.
L'archive ouverte pluridisciplinaire $\mathbf{H A L}$, est destinée au dépôt et à la diffusion de documents scientifiques de niveau recherche, publiés ou non, émanant des établissements d'enseignement et de recherche français ou étrangers, des laboratoires publics ou privés. 


\section{Informalising Readmission Agreements in the EU Neighbourhood}

\section{Jean-Pierre Cassarino}

The conclusion of agreements linked to the readmission of migrants to their country of origin has gained momentum since the 1990s, particularly following the June 2002 Seville European Council which called for stronger cooperation in this field with third (or non-EU) countries. This trend reflects the fact that the issue of readmission is gradually pervading various policy areas, not only the migration and asylum policy of the EU and its member states, but also their trade and development aid policy, as well as their international relations.

Readmission agreements are concluded to facilitate the removal or expulsion of "persons who do not or no longer fulfil the conditions of entry to, presence in or residence" 1 in a destination country. "Persons to be readmitted [or removed] under such agreements are a country's own nationals and, under certain conditions, third-country nationals or stateless persons who have passed [or transited] through the territory of the requested country or otherwise been granted permission to stay there". ${ }^{2}$

Some Central Eastern European countries (CEECs) with a real prospect of accession to the European Union (EU) have been quite collaborative (if not pro-active) in readmission talks and negotiations, and these have led to the conclusion of numerous bilateral agreements with EU member states. Countries like Bulgaria and Romania, which joined the EU in January 2007, had a concrete incentive to cooperate on readmission while substantially justifying their option to their constituencies by pointing out the expected post-accession benefits. Similarly, for those Eastern European countries wishing to keep the European door open, even though they have no clear long-term prospect of EU membership (for example, Ukraine and Moldova), substantial progress has also been made on readmission talks and visa facilitations.

\footnotetext{
Jean-Pierre Cassarino is Scientific Coordinator of the MIREM project at the Robert Schuman Centre for Advanced Studies, Florence, Italy. The author is grateful to anonymous reviewers as well as to Brad Blitz, Paolo Cuttitta, Lourdes Hernandez Martin, Antonella Guarneri and Nathalie Tocci for their helpful comments and criticisms on an earlier draft; Email: JPCassarino@EUI.eu.

${ }^{1}$ European Commission, Community Return Policy on Illegal Residents, 26.

${ }^{2}$ Definition of the Intergovernmental Consultations for Asylum, Refugee and Migration Policies in Europe, North America and Australia. IGC Report on Readmission Agreements, 9.
} 
Conversely, bilateral negotiations on readmission with Mediterranean countries which have no prospect of accession to the EU have been lengthier and much more complicated. Moreover, when readmission agreements have been concluded, their final aim (that is, the removal of illegally staying nationals of third countries) has been hindered by administrative obstacles and a lack of cooperation from the authorities of the signatory country.

Faced with the difficulties inherent in the conclusion and concrete implementation of formal readmission agreements with Mediterranean countries, some European countries have recently started to devise a broader framework of cooperation based on administrative arrangements, bilateral deals and exchanges of letters and memoranda of understanding as an alternative to formal readmission agreements, arguing that these new forms of "compromise" foster cooperation on readmission. Though they are not formal agreements, they nevertheless have serious implications on state-to-state relations and migrants' rights to protection.

In order to understand the emergence, if not proliferation, of these readmission arrangements, the accepted view that the cooperation of Mediterranean countries is dictated by pressures exerted by the EU and its member states has to be set aside. This article sets out to identify the various factors which have driven some Mediterranean countries to cooperate on readmission with EU member states such as France, Italy and Spain, and how this has led to the gradual "informalisation" of agreements linked to readmission. The aim is to understand more thoroughly what this strategic option implies in terms of costs, benefits and effectiveness. Do these arrangements provide a concrete added-value in the fight against illegal migration and in the management of removals? Are they instruments that have been adaptively shaped to respond to other concerns? Finally, the article looks into the implications of such arrangements.

\section{Readmission - a growing concern}

\section{The rationale}

Many scholars from various disciplines have already stressed the fact that bilateral cooperation on readmission is not new in the history of international relations ${ }^{3}$ and that, since the early 1990s, the issue of readmission has become part and parcel of the immigration control systems developed at bilateral and multilateral levels. ${ }^{4}$

The forced return of a person to his/her country, and the need to facilitate this return, has been mentioned in various international documents, most

\footnotetext{
${ }^{3}$ Kruse, "EU Readmission Policy and its Effects", 120; Bouteillet-Paquet, "Passing the Buck", 359.

${ }^{4}$ Lavenex, "EU Trade Policy and Immigration Control", 161-77. See also Schieffer, "Community Readmission Agreements with Third Countries", 343-57. For a thorough legal approach to bilateral and multilateral readmission agreements, see Nascimbene, "Relazioni esterne e accordi di riammissione", 297-310.
} 
recently, in the 2001 Protocol against the Smuggling of Migrants by Land, Air and Sea, supplementing the United Nations Convention against Transnational Organised Crime. The need to define provisions aimed at concretely facilitating the return and readmission of persons has gradually become a priority in regional and international migration talks. Article 18 of the 2001 Protocol emblematically illustrates this by stating that "each State Party agrees to facilitate and accept, without undue or unreasonable delay, the return of a person". Similarly, the Berne Initiative, ${ }^{5}$ the $5+5$ Dialogue, ${ }^{6}$ the Prüm Treaty ${ }^{7}$ and, more recently, the Rabat Declaration resulting from the July 2006 EuroAfrican ministerial conference on migration and development, constitute other regional and international fora where the participating states jointly agree to facilitate, among other things, bilateral cooperation on readmission. ${ }^{8}$

The vast majority of readmission agreements are concluded at the bilateral level. They set out administrative and operational procedures jointly regulating the means of identifying undocumented migrants and the ensuing issue of travel documents (or laissez-passers). The agreement specifies the national authorities in charge of cooperating on the removal of the foreigners as well as the border control points which may be used for readmission purposes.

\section{Obligations between unequal parties}

Contracting parties agree to readmit, at the request of the other, nationals (or, if so agreed, nationals of third countries) who do not or no longer fulfil the conditions of entry or residence in the territory of the requesting State.

\footnotetext{
${ }^{5}$ The Berne initiative, launched in June 2001 under the aegis of the Swiss Government and in cooperation with the International Organisation for Migration (IOM), is aimed at favouring an informal intergovernmental dialogue on migration among sending, transit and destination countries with a view to supporting the sharing of information and initiatives relating to the management of migration flows.

${ }^{6}$ The $5+5$ Dialogue, launched in Rome in 1990, following a high-level meeting of the Ministers of Foreign Affairs of France, Italy, Spain, Portugal, Malta, Mauritania, Morocco, Algeria, Tunisia and Libya, is aimed at fostering a regional political and economic cooperation process in the Western Mediterranean. Owing to the civil war in Algeria and the embargo on Libya, the 5+5 Dialogue actually only started in 2001, when Portugal decided to revitalise it. Since then, cooperation on the management of migration flows and the fight against illegal migration have been an integral part of the $5+5$ Dialogue agenda.

${ }^{7}$ The Prüm Treaty or Convention was signed on 27 May 2005 by seven EU member states including Austria, Belgium, France, Germany, Luxembourg, The Netherlands and Spain. Bulgaria, Finland, Italy, Portugal, Romania, Slovakia, Slovenia and Sweden are waiting to join. The Convention is aimed at stepping up cross-border police cooperation and exchanges between members' law enforcement agencies with a view to combating organised crime, terrorism and illegal migration more effectively. Moreover, art. 23 of the Convention foresees operational cooperation specifically regarding the forced repatriation of illegally staying third-country nationals through the organisation of joint flights for removals.

${ }^{8}$ This conference was jointly organised on 10-11 July 2006 by Morocco, Spain and France, and gathered the EU member states as well as countries from West, Central and South Africa. 57 countries signed the Rabat Declaration aimed at fostering a close partnership on the management of legal and illegal migration, http://www.maec.gov.ma/migration/Doc/RABAT\%20DECLARATION_EN.pdf.
} 
Importantly, they also agree to carry out removal procedures without unnecessary formalities and within a reasonable time limit, in due respect of their duties under their national legislation and international agreements on human rights and the protection of the status of refugees, in accordance with the 1951 Geneva Convention relating to the status of refugees and its 1967 protocol.

This reciprocity of obligations does not mean that the contracting parties benefit equally from the conclusion and implementation of the readmission agreement. To use Robert Keohane's words, readmission agreements characterise "relations among unequals", above all when they involve two signatory countries that have a significant level of developmental asymmetry, which is more often than not the case. It could even be argued that the obligations contained in readmission agreements are typically unequal, although framed in a reciprocal context.

International relations abound with bilateral agreements having unequal benefits. In this case, inequality lies in the structural institutional and legal capacity of the contracting parties to deal with the removal of aliens, whether citizens of the contracting parties or of third countries, but also in the asymmetrical impact of implementation of the agreement. Furthermore, the perceived costs and benefits of readmission agreements differ substantially for the contracting parties. While the interest of a destination country seems obvious ("unwanted migrants have to be effectively removed"), the interest of a country of origin may be less evident, above all when considering that its economy remains dependent on the revenues of its (legal and illegal) expatriates living abroad, or when migration continues to be viewed as a safety valve to relieve pressure on domestic unemployment.

It follows from the foregoing considerations that a legalistic approach does not suffice to delve into the dynamics that sustain bilateral cooperation on readmission. While the conclusion of a readmission agreement is motivated by expected benefits which are unequally perceived by the contracting parties, its full implementation is based on a balance between the concrete benefits and costs attached to it. As will be explained, reciprocal obligations are not sufficient to account for it, nor are they sufficient to secure its effectiveness.

\section{The unstable balance of costs, benefits and defection}

From a contractual point of view, readmission agreements involve two sovereign states, one state (soliciting state) soliciting cooperation on readmission from another (the solicited state). Recurrent exchanges precede the bilateral negotiations during which the expected benefits and costs of the cooperation are evaluated by both states. These informal exchanges resemble

\footnotetext{
${ }^{9}$ Keohane, "Reciprocity in International Relations", 6.
} 
a learning process where the costs and benefits of the cooperation are evaluated.

Benefits for soliciting states may be tangible and intangible. Cooperation is expected to speed up the process of identifying aliens subject to removal orders and to lower the average costs of their detention, which are reportedly high in EU member states. ${ }^{10}$ At the same time, the conclusion of readmission agreements may be presented by the government of the soliciting state to its public opinion and the media as an additional means to manage migration flows and to protect its citizens.

Benefits for solicited states may include various compensatory measures: special trade concessions, the accession to a regional trading bloc, preferential entry quotas for economic migrants, technical cooperation, increased development aid, and entry visa facilitations have been the most common incentives used by EU member states. But there may be intangible benefits from cooperation on readmission as well. Solicited states may be motivated by their desire to be seen as credible players in the international arena with a view to gaining further international legitimacy.

The costs of a readmission agreement are borne predominantly by the solicited state. While the costs for the soliciting country may be linked to the uncertainty surrounding the full implementation of the agreement, those for the solicited state arise above all from the substantial structural institutional and legal reforms required, which could have a disruptive impact on statesociety relationships and on the domestic economy. Moreover, other costs may arise when the effects of the agreement are negatively perceived by the population of the solicited country itself or by its expatriates abroad.

The perceived value of the exchanged items shapes the intensity of the quid pro quo. However, the balance between the costs and benefits can change over time. In the long run, the concrete benefits might turn out to be too weak with respect to the unintended costs of the bilateral cooperation on readmission. This change of value might negatively impact on the effective implementation of a readmission agreement and lead gradually to defection.

For example, Morocco and Spain concluded a readmission agreement in February 1992 which covered readmission of nationals of the contracting parties as well as removal of illegal third-party nationals and stateless persons. To date, this agreement has never been fully implemented owing to the reluctance of the Moroccan authorities to accept readmission of third-country nationals originating mainly from sub-Saharan Africa who purportedly transited through Morocco before being apprehended on Spanish territory. Indeed, Morocco has frequently questioned whether migrants actually transited through its territory before arriving in Spain, arguing that they transited through Algeria.

\footnotetext{
${ }^{10}$ The average cost in Europe's detention centres varies from $€ 60$ to $€ 100$ per day per capita. Jesuit Refugee Service - Europe, Observation and Position Document.
} 
Morocco agreed to sign the readmission agreement as part of a reconciliation process with its Spanish neighbour which followed the signing of a Treaty of Good-neighbourliness and Friendly Cooperation on 4 July 1991. At the time, the migration of sub-Saharan nationals transiting through Morocco en route to Spain and the EU was not viewed as significant. Also, Morocco's acceptance to conclude this agreement was motivated by its ambition to acquire a special status in its political and economic relationships with the European Union. ${ }^{11}$

However, the Moroccan defection did not result only from the emergence of unexpected costs of the concrete implementation of the agreement. Diplomatic tensions with Spain, particularly under the government of José Maria Aznar, ${ }^{12}$ which culminated in the early 2000s, hampered the implementation of the agreement.

Thus, changing circumstances may upset the balance of costs and benefits and be conducive to defection. Defection has a cost for both contracting parties. The defecting party may be viewed as unreliable, while the ability of the other party to exert a strong leverage to secure cooperation may be questioned. However, as Charles Lipson ${ }^{13}$ demonstrated, not all defections discredit. Actually, some may be excusable because circumstances have changed significantly, others may be understandable because the concrete implications of the agreement turn out to be unexpectedly disruptive. A new round of consultations usually takes place in order to overcome the impediments to implementation.

\section{Strategic embeddedness}

As the abovementioned Spanish-Moroccan case study shows, the conclusion of a readmission agreement is rarely isolated from a broader framework of interaction and cooperation. Often, its conclusion results from a rapprochement which in turn stems from the gradual strengthening of diplomatic relations. In this sense, a readmission agreement is just one of many means of consolidating a bilateral cooperative framework including other strategic (and perhaps more crucial) policy areas.

The recent (formal) readmission agreement signed in July 2006 between the United Kingdom and Algeria, but still not enforced, is a similar case. This agreement - limited to the removal of the illegally staying nationals of the contracting parties - was reached in the context of a round of negotiations including such strategic issues as energy security, the fight against terrorism and police cooperation. These strategic issues have become top priorities in

\footnotetext{
${ }^{11}$ Mrabet, "Readmission Agreements: Morocco", 379-85.

${ }^{12}$ As a result of the Persil island crisis and other related diplomatic tensions, see Gillespie, "This Stupid Little Island", 110-32.

${ }^{13}$ Lipson, "Why are Some International Agreements Informal?", 495-538.
} 
bilateral relations between the UK and Algeria, particularly following the July 2005 G-8 meeting in Gleneagles which Algeria also attended.

As it is embedded in a broader strategic framework, the issue of readmission may weave through various bilateral cooperative levels. The more two state actors interact (whether successfully or unsuccessfully), the more they learn about each other, and the more they reciprocally understand the costs and benefits attached to cooperation on readmission, the more they will be inclined to determine their cooperative framework adaptively and jointly in response to the changing balance of costs and benefits.

The recurrent informal exchanges preceding the bilateral negotiations during which the expected benefits and costs of the cooperation are evaluated by both parties constitute a learning process. So does the re-negotiation process, during which the actors learn how to adapt their claims to the capacity of their counterparts. This may bring about other patterns of cooperation on readmission, which are not necessarily framed in a formal readmission agreement, and which are adaptively shaped by the responsiveness of the state actors involved.

Indeed, the various rounds of negotiations taking place at bilateral and multilateral levels have allowed both EU member states (particularly Italy, France and Spain) and their South Mediterranean counterparts to adaptively develop alternative patterns of cooperation on readmission. They are not formal readmission agreements, but are agreements linked to readmission that have been formed and transformed according to various concerns.

\section{The emergence of informal patterns of bilateral cooperation on readmission}

An inventory of all the bilateral readmission agreements concluded between the EU-27 member states and third countries would not suffice to illustrate the various mechanisms and cooperative instruments that have emerged over the last decade to sustain the removal of illegally staying third-country nationals.

The parties may decide to conclude a standard readmission agreement because both view this as being valuable to their interests or because the solicited state needs to act as a credible partner in exchange for concrete benefits.

Under some circumstances, however, both parties may agree to cooperate on readmission issues without necessarily formalising their cooperation. They may opt to deal with the issue of readmission using other types of deals, including exchanges of letters and memoranda of understanding or by couching it in a broader framework of cooperation including additional forms of mutual assistance (e.g., police cooperation agreement, arrangements).

These alternative patterns of cooperation linked to readmission but not formalised as readmission agreements are by their nature difficult to detect. Being informal, they are not usually published in official bulletins, nor are they 


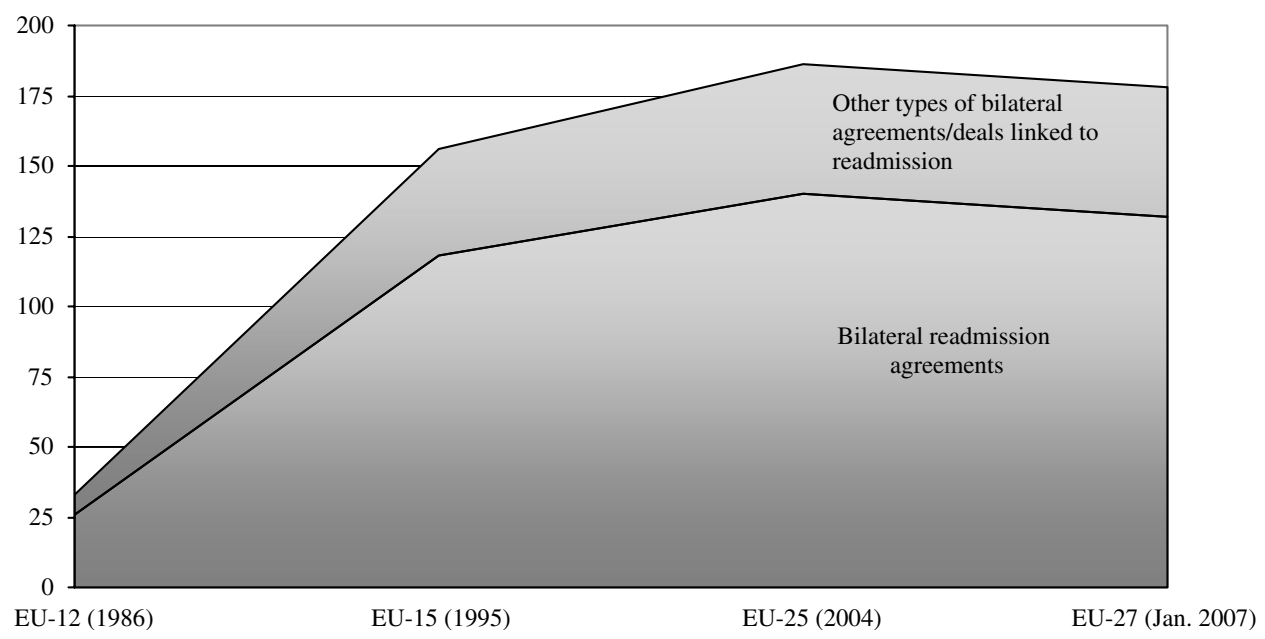

FIG. 1. From the EU-12 to the EU-27: Agreements linked to readmission concluded by the EU member states with third (or non-EU) countries

Source: MIREM, www.mirem.eu. Other types of deals include memoranda of understanding, exchanges of letters, and police cooperation agreements including a clause of readmission.

recorded in official documents or correspondence. ${ }^{14}$ However, they can be traced in that they are, just like formal readmission agreements, embedded in a strategic framework of bilateral cooperation. There are perceptible signs which indicate that two countries may or may not be willing to negotiate or conclude a deal on readmission, depending on circumstances in their broadest sense, that is, the ways in which they interact, the size and nature of the migration flows affecting both countries, and (to a lesser extent) their geographical proximity.

Figure 1 plots data obtained from the Ministries of Foreign Affairs and of the Interior of the $27 \mathrm{EU}$ member states. The sharp increase in the number of bilateral readmission agreements reflects the growing importance that the issue of readmission has acquired in the international relations of the EU member states over the last decades. France, Germany, Greece, Italy and Spain are the most involved in formal readmission agreements and in ongoing negotiations with third countries on this matter. Indeed, in January 2007, more than half of the total number of agreements linked to readmission (that is, 54.6 percent of the 178 agreements reported on the above graph) were concluded by these five member states. Their share was even higher a few years before the 2004 EU enlargement. More importantly, these five EU member states are those that have been most predominantly engaged in other patterns of

\footnotetext{
${ }^{14}$ For example, in Italy, in accordance with art. 4 of Decree 286/1998, the Ministries of Foreign Affairs and of the Interior are by law entitled to conclude bilateral repatriation deals with third countries. The Italian executive may conclude such bilateral deals without the prior authorisation of the Parliament. For a comprehensive legal analysis, see Favilli, "Quali modalità di conclusione?", $156-65$.
} 
bilateral cooperation on readmission issues, which were not formalised as readmission agreements.

The significant growth in the number of bilateral readmission agreements also illustrates the responsiveness of various third countries to the EU's call for such agreements. As mentioned earlier, various countries in the Western Balkans and Eastern Europe have had concrete incentives to do so, either because of their candidate country status (for example, Macedonia) or as part

of their negotiations on a Stabilisation and Association Agreement (for example, Serbia and Bosnia-Herzegovina). Others have been less inclined to conclude formal readmission agreements.

Table 1 shows the regional distribution of all agreements linked to readmission. While most formal readmission agreements have been concluded with non-EU countries in Eastern Europe and the Balkans (87 out of 132), more than two thirds of the informal agreements linked to readmission (that is, memoranda of understanding, exchanges of letters, police cooperation agreements including a clause on readmission and other deals) are with countries in the South and East Mediterranean and Africa (32 out of 46).

Thus there are two geographic ensembles (Eastern Europe and the Balkans, and the South Mediterranean and Africa) which differ from one another in terms of patterns of cooperation on readmission issues with the EU member states. The differences stem not only from the number of agreements concluded, but also from the patterns of cooperation: they are rather homogenous in the case of Eastern European and Balkan countries (87 out of 91 agreements are formal readmission agreements) and extremely heterogeneous in the case of Southern and Eastern Mediterranean countries, particularly those in the Maghreb.

\section{The emergence of a new compromise}

The main rationale for the adoption of informal deals is to secure bilateral cooperation on readmission and to avoid defection as far as possible by responding flexibly to new situations. Various EU member states have been prone to readjust their cooperative patterns with some Mediterranean third countries with a view to addressing the pressing problem of re-documentation, that is, the delivery of travel documents or laissez-passers by the consular authorities of the third country needed to remove undocumented migrants. Repeated consultations allow for readjustment with a view to complying with the terms of the bilateral arrangements and to securing a modicum of policy transfer - all of this is part of a learning process. ${ }^{15}$

\footnotetext{
${ }^{15}$ Dolowitz and Marsh, "Learning from Abroad", 5-24.
} 


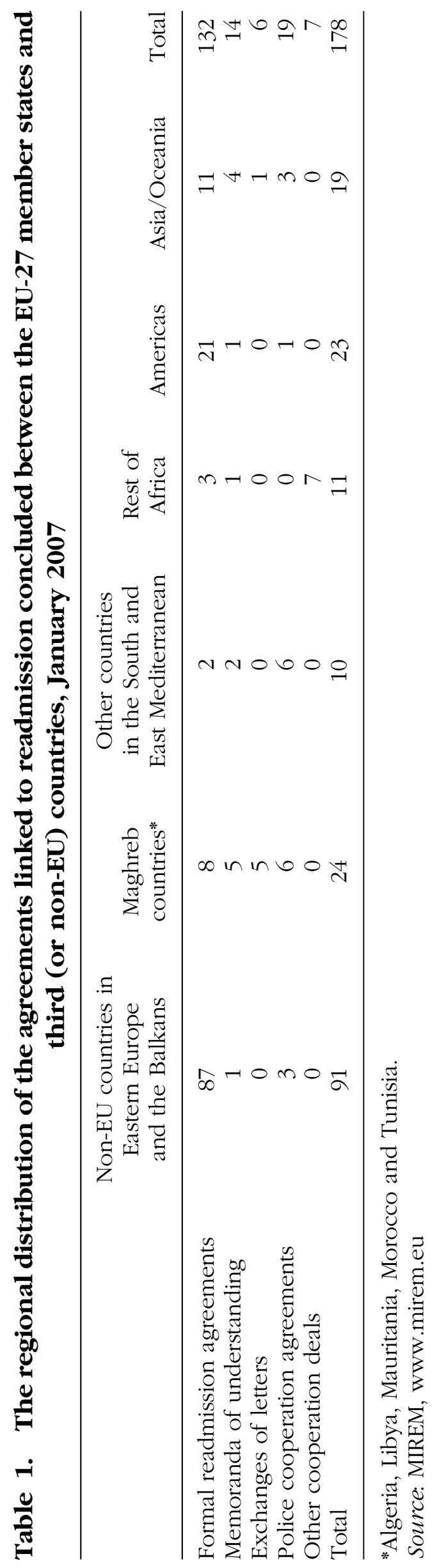


Stating that countries in the South and East Mediterranean have had less incentive to cooperate on readmission than countries in Eastern Europe and the Balkans does not fully explain why the former have engaged in informal deals; nor does it adequately account for the gradual consolidation of such deals. A look has to be taken at the characteristics of such arrangements.

- The first characteristic is their low level of public visibility. In Mediterranean countries of origin, the issue of readmission is rather unpopular, and governments in these countries do not like to publicise their cooperation in this field, because it would tarnish their relationship with their expatriates and their populations and because it would convey a negative image of them as vassals of the dominant European powers.

- The second characteristic pertains to their adaptability to changing circumstances and the consequential need to renegotiate their terms. In contrast to formal readmission agreements requiring a lengthy ratification process, informal agreements can be easily renegotiated if new situations and claims so require.

- The third characteristic is the limited cost of defection. While defection applies equally to any kind of international bargain, it arguably has a lower cost when it applies to an informal arrangement. It may be viewed as stemming from the changed balance of costs and benefits.

- The fourth characteristic of these arrangements is their relationship to domestic and regional security concerns. The externalisation of the migration and asylum policies of the EU and its member states, plus the pro-active involvement of Mediterranean countries in enhanced control of the EU's external borders ${ }^{16}$ have contributed gradually to placing the issue of readmission within a set of strategic initiatives in the field of Justice and Home Affairs. Various police cooperation arrangements which foresee delivery of sophisticated technical equipment aimed at combating illegal migration and at controlling borders have been concluded with Mediterranean countries. ${ }^{17}$ South Mediterranean countries (particularly Algeria, Egypt, Libya, Mauritania, Morocco and Tunisia) have been involved with their European neighbours in various bilateral and multilateral police operations such as the Neptune project, ${ }^{18}$ the

\footnotetext{
${ }^{16}$ Lutterbeck, "Policing Migration in the Mediterranean", 59-82.

${ }^{17}$ Cuttitta, "Controllo dell'immigrazione tra Nordafrica e Italia", 169-99.

${ }^{18}$ The Neptune project is a joint operation aimed at strengthening EU sea border control in the Mediterranean. Introduced by Italy during its 2003 EU Presidency, the project began in September 2003 and has, since then, been backed by Cyprus, France, Germany, Greece, Malta, the United Kingdom, the Netherlands, Spain and Europol. A joint centre of surveillance was established in Palermo to prevent and act quickly against illegal migration and human trafficking in the Mediterranean. Tunisia has been mobilised in the context of the Neptune project as of January 2004.
} 
NATO-led maritime Operation Active Endeavour, ${ }^{19}$ the Atlantis project ${ }^{20}$ and more recently the Seahorse project. ${ }^{21}$ These police cooperation initiatives have led to the emergence of unprecedented patterns of interconnectedness ${ }^{22}$ between the North and the South of the Mediterranean. They aim to strengthen cooperation links between the law-enforcement agencies of the parties and enhance their regime legitimacy and international credibility in the management of migration and borders.

These four characteristics (invisibility, flexibility, limited cost of defection, adaptability to security concerns) are sufficient to explain the gradual proliferation of informal patterns of cooperation on readmission in the Mediterranean region and beyond. They are also the key to understanding why some Mediterranean countries choose to cooperate on readmission with some EU member states despite their vocal reluctance to formalise their cooperation or to implement their formal agreements fully.

\section{The three-pronged approach}

It is important to stress that successful cooperation on security and border control issues in the Euro-Mediterranean area has led to an extension southward from the Mediterranean towards sub-Saharan Africa.

Two interrelated reasons explain this. The first is that the EU and its member states are intent on cooperating directly with migrants' source countries in sub-Saharan Africa in an attempt to mobilise them in the joint management of international migration, particularly in the fight against illegal migration. The second reason is that various EU member states, particularly France, Italy and Spain, are becoming aware of the need to strike agreements with sub-Saharan source countries with a view to alleviating the burden of the readmission of third-country nationals on strategic North African countries and to securing the latter's cooperation on the reinforced control of the EU's external borders.

Through their "pro-active diplomacy", France, Italy and Spain have recently been in the forefront in promoting a new wave of cooperation agreements

\footnotetext{
${ }^{19}$ Operation Active Endeavour aims to prevent or counter terrorism, human trafficking and the smuggling of arms. Following the NATO Summit in Istanbul on 28 June 2004, the Alliance decided to enhance Operation Active Endeavour, including Mediterranean Dialogue countries such as Algeria, Israel and Morocco, which had expressed interest in being involved in control actions.

${ }^{20}$ The Atlantis project follows an agreement signed on 4 December 2003 between Spain and Morocco aimed at organising joint sea border police patrols to combat illegal migration and human trafficking in the area surrounding the Canary Islands and in the straits of Gibraltar (Resmann, "Immigration Management in Spain").

${ }^{21}$ Led by the Spanish Guardia Civíl, the main objective of the project launched in 2006 is to cooperate with Mauritanian law enforcement agencies to reinforce maritime border controls.

${ }^{22}$ Cassarino, "Migration and Border Management in Euro-Mediterranean".
} 
which cover, among other things, the issue of readmission. More precisely, these agreements are based on a three-pronged approach covering:

- police cooperation (including readmission);

- reinforced border control;

- the joint management of economic migration coupled with increased development aid with a view to addressing the root causes of migration.

This approach draws significantly on a project that Italy presented during its EU presidency in $2003 .^{23}$ Linking the issue of readmission to an array of $a d$ hoc measures ranging from debt relief, development aid, poverty-reduction projects, police cooperation agreements aimed at fighting organised crime and human-trafficking, and cooperation between law-enforcement agencies, it is now an integral part of Spain's Plan África ${ }^{24}$ and of France's "politique de co-développement fondée sur trois volets". ${ }^{25}$ It is still too early to tell, however, whether it will lead to concrete progress in the field of migration management.

Is this strategy likely to foster the conclusion of formal readmission agreements? To be clear, the objective is to find swift and quiet arrangements for readmission, not to pave the way for formal readmission agreements.

In an interview in May 2006, Spanish Foreign Minister Miguel Angel Moratinos, stated that:

[t]he old approach to readmission agreements has to be complete with other approaches. This is not to say that we should renounce the need for readmission. However, to put this into practice, sending countries need an array of incentives to accept the removal of their citizens. ${ }^{26}$

Moratinos' statement reflects the growing awareness - shared by most officials and policymakers in the EU member states - that a new compromise needs to be considered in their interaction with third countries in the Mediterranean and the African continent regarding the thorny issue of readmission. This shift is not so much in the incentives offered to third country governments as in the design of alternative mechanisms allowing quick and discreet solutions linked to other strategic issues.

Just like Spain, France and Italy are becoming increasingly aware of the need for innovative patterns of cooperation on readmission issues with these third countries. Their adaptive inclination has become more of a necessity than a choice.

The numerous bilateral police cooperation initiatives that have developed over the last three years have allowed some Mediterranean third countries (above all the Maghreb countries) to gain international credibility and regime

\footnotetext{
${ }^{23}$ EU Council, Programme of Measures to Combat Illegal Migration.

${ }^{24}$ Spain's Plan África targets such African countries as Burkina Faso, Cameroon, Chad, Congo, Coted'Ivoire, Ethiopia, Guinea Bissau, the Democratic Republic of Congo, Mauritania, Senegal, Somalia, Tanzania and Uganda. Ministerio de Asuntos Exteriores y de Cooperación, Plan África.

${ }^{25}$ Assemblée Nationale, "Compte rendu intégral", 8256.

${ }^{26}$ (Translated from the Spanish) Ministerios de Asuntos Exteriores, "La crisis de Canarias".
} 
legitimacy and to acquire a strategic position in migration talks. Manifestly, this has allowed some Mediterranean countries to act not only as credible players in migration talks but also as equal players expressing their own views and expectations. An emblematic example is the public statement of the Moroccan Delegate Minister for Foreign Affairs and Cooperation, Taieb Fassi Fihri, at the Euro-African Conference on Migration and Development, held in Rabat in July 2006:

No country has the capacity to control its own migration flows [... The European Union] should not externalise its actions towards one country [i.e., Morocco] under the pretext that the latter is the last country of transit for migrants en route to the European coasts.... If readmission agreements are concluded with each partner [of the African continent], Morocco will no longer have the problems it is facing. ${ }^{27}$

Fihri's explicit message called on the EU and its member states to conclude additional readmission agreements with other transit and origin countries in the Maghreb and sub-Saharan Africa, as a prerequisite for reinforcing cooperation on readmission with Morocco. This position reflects a conditionality that the Moroccan government has determinedly defended over the last three years. This reversed conditionality would hardly have been acceptable and justifiable had Morocco not acquired a strategic position, as well as international credibility in the field of bilateral police cooperation and border controls.

\section{Conclusion: implications for policymaking}

A whole spectrum of formal and informal agreements addressing the readmission issue has been emerging over the last decade. Formal readmission agreements constitute just one pattern of cooperation. Furthermore, while incentives play a crucial role in inducing third countries to cooperate on readmission, they do not adequately account for the sustainability of bilateral cooperation in the long term. The perceived costs and benefits facing each country shape the durability as well as the pattern of cooperation.

The issue of readmission tends not to be tackled in isolation but in close connection with other issues of common concern. Given the asymmetry in benefits that characterises cooperation between Mediterranean countries and EU member states, alternative solutions have been found to ensure flexible cooperation on readmission. The objective remains unchanged, but in relations with Southern Mediterranean countries, the emphasis has been placed more on pragmatic steps than on the conclusion of formal agreements. Actually, the operability of the cooperation on readmission has been prioritised over its formalisation.

\footnotetext{
${ }^{27}$ Moroccan Ministry of Foreign Affairs, "Speeches, Declarations and Interviews".
} 
This shift in priority has various implications in terms of policymaking. First, the conclusion of these arrangements might hinder the EU's attempt to reach Community readmission agreements. The European Commission was mandated to negotiate readmission agreements with two countries in the Mediterranean area, Morocco and Algeria, respectively in September 2000 and November 2002. Since then, the circumstances as well as the terms of the negotiation process have changed substantially. Indeed, the participation of both Maghreb countries in control of EU external borders and their police cooperation with some EU member states might have weakened the valueadded inherent in the conclusion of a Community readmission agreement.

The European Commission has become increasingly aware of these changed circumstances and of the need to devise new solutions. In a communication dated 30 November 2006, it expressed its intention to "broker a deal" 28 with a view to facilitating the conclusion of Community readmission agreements with third countries while learning from the recent experience of the EU member states. It is not yet clear how this deal will be fashioned. It is likely, however, that the Commission may be inclined to revamp its framework of cooperation with Morocco and Algeria. This adaptive inclination also seems to be motivated by the need to send a clear message to EU member states, particularly those involved in the G-6 and the Prüm Treaty, which have expressed mounting criticism regarding the lengthy negotiation processes for Community readmission agreements.

Second, the low level of public accountability of these informal arrangements raises serious concerns regarding the extent to which the removal procedures implemented by participating states can be monitored to ensure full compliance with European and international law on the rights of persons subject to a removal order, whether illegal migrants or rejected asylumseekers. Reports on the actual impact of these arrangements remain beyond public purview, making any form of public critique disputable or groundless and easy to deny. The Libyan-Italian arrangements for the readmission of illegal aliens constitute an emblematic case study. The UNHCR and various human rights associations and organisations denounced the collective expulsions of asylum-seekers to Libya that Italy organised between October 2004 and March 2005. In April 2005, the European Parliament adopted a resolution calling on Italy to refrain from collective expulsions stating that "Italian authorities have failed to meet their international obligations by not ensuring that the lives of the people expelled by them are not threatened in their countries of origin". ${ }^{29}$ Yet, these public denunciations were curtly rejected by former Minister of the Interior, Giuseppe Pisanu, who replied that "all the expulsions [to Libya] were considered individually, in accordance with Italian law and the principles of international law, on the basis of

\footnotetext{
${ }^{28}$ EC Commission, The Global Approach to Migration One Year On, 9.

${ }^{29}$ European Parliament resolution on Lampedusa, 14 April 2005, P6_TA(2005)0138; Human Rights Watch, "Stemming the Flow"; Cuttitta, "Il controllo dell'immigrazione tra Nordafrica e Italia".
} 
arrangements with Libya and Egypt, and despite the absence of any formal readmission agreement". 30

Third, this emerging pattern of cooperation on readmission - which has become part and parcel of the security agenda of some EU member states and some Mediterranean countries - has led to judicial and police reforms in those Mediterranean countries as well as to enhanced technical assistance to police forces and law-enforcement agencies aimed at strengthening their border management capabilities. One is entitled to question the extent to which the prioritisation of such security concerns is compatible with the promotion of good governance, democracy and public accountability in these countries, ${ }^{31}$ as well as with the development of a genuine legal system aimed at respect for the rights of migrants and the protection of asylum-seekers.

A new compromise is emerging in the field of readmission, resulting predominantly from the convergence of short-term security concerns. It reflects the emergence of power relations which substantially differ from the ones that prevailed a few years ago and which are leading to flexible patterns of cooperation on readmission. However, these new patterns of cooperation may not be self-sustaining in the long term if they continue to give priority to security concerns over the pressing development problems facing Mediterranean and African countries. These remain the root causes of migration flows and refugee movements, together with poverty and the search for civil and political rights.

\section{References}

Allied Joint Force Command Naples. "Operation Active Endeavor". http://www.afsouth. nato.int/JFCN_Operations/ActiveEndeavour/Endeavour.htm.

Assemblée Nationale. "Compte rendu intégral: $2^{\text {ème }}$ séance du mardi 13 décembre 2005", Journal Officiel de la République Française, no. 107[2] A.N. (C.R.) 2005: 8256.

Assembly of Western European Union. Security and Stability in the Mediterranean Region, Document A/1939, 52nd session, 20 June 2006 (Paris: WEU, 2006). http://www.assemblyweu.org/en/documents/sessions_ordinaires/rpt/2006/1939.php?PHPSESSID = f3137d60.

Bouteillet-Paquet, D. "Passing the Buck: A Critical Analysis of the Readmission Policy Implemented by the European Union and its Member States", European Journal of Migration and Law, 5 (2003): 359-77.

Cassarino, J.-P. "Migration and Border Management in the Euro-Mediterranean Area: Heading towards New Forms of Interconnectedness", Med 2005. Barcelona: European Institute of the Mediterranean (IeMed) and Fundació CIDOB, 2005: 227-31. http://www.iemed.org/ anuari/2005/anarticles/ancassarino.pdf.

\footnotetext{
${ }^{30}$ (Translated from the Italian) Comunicazione del Ministro dell'Interno al Senato della Repubblica. For a study on the lack of transparency surrounding Italian-Libyan cooperation on removals, see Favilli, "Quali modalità di conclusione?", 159.

${ }^{31} \mathrm{WEU}$, Security and Stability in the Mediterranean Region.
} 
Commission of the EC. Communication from the Commission to the Council and the European Parliament on a Community Return Policy on Illegal Residents, COM (2002) 504 final: 26.

Commission of the EC. Communication from the Commission to the Council and the European Parliament: The Global Approach to Migration One Year On: Towards a Comprehensive European Migration Policy, COM (2006) 735 final: 9.

Council of the European Union. Programme of Measures to Combat Illegal Migration across the Maritime Borders of the Member States of the European Union, 15236/03 FRONT 170 COMIX 717, 28 November 2003.

Cuttitta, P. "Il controllo dell'immigrazione tra Nordafrica e Italia". In Libro Bianco: I Centri di Permanenza temporanea e Assistenza in Italia, edited by $\mathrm{N}$. Dentico and M. Gressi, 169-99, Rome: Gruppo di Lavoro sui CPTA in Italia, 2006. http:// www.comitatodirittiumani.org/LB/Capitolo\%205.pdf.

Dolowitz, D. P. and D. Marsh. "Learning from Abroad: The Role of Policy Transfer in Contemporary Policy-Making", Governance: An International Journal of Policy and Administration, 13, no. 1 (2000): 5-24.

Euro-African Partnership for Migration and Development. "Rabat Declaration". http:// www.maec.gov.ma/migration/Doc/RABAT\%20DECLARATION_EN.pdf.

European Parliament. European Parliament resolution on Lampedusa, 14 April 2005, P6_TA(2005)0138. http://www.europarl.europa.eu.

Favilli, C. "Quali modalità di conclusione degli accordi internazionali in materia di immigrazione?", Rivista di diritto internazionale, 88 (2005): 156-65.

Gillespie, R. "'This Stupid Little Island': A Neighbourhood Confrontation in the Western Mediterranean", International Politics, 43 (2006): 110-32.

Human Rights Watch. "Stemming the Flow: Abuses Against Migrants, Asylum-Seekers and Refugees", Human Rights Watch Report, 18, no. 5(E) (September 2006). http:// www.hrw.org/reports/2006/libya0906/.

Intergovernmental Consultations for Asylum, Refugee and Migration Policies in Europe, North America and Australia (IGC). IGC Report on Readmission Agreements. Geneva: IGC, January 2002.

Jesuit Refugee Service - Europe. Observation and Position Document, Brussels, 17 October 2005. http://www.detention-in-europe.org.

Keohane, R. "Reciprocity in International Relations", International Organization, 40, no. 1 (1986): 1-27.

Kruse, I. "EU Readmission Policy and its Effects on Transit Countries - The Case of Albania", European Journal of Migration and Law, 8, no. 2 (2006): 115-42.

Lavenex, S. "EU Trade Policy and Immigration Control". In Migration and the Externalities of European Integration, edited by S. Lavenex and E. M. Uçarer, 161-7, Oxford: Lexington Books, 2002.

Lipson, C. "Why are Some International Agreements Informal?", International Organization, 45, no. 4 (1991): 495-538.

Lutterbeck, D. "Policing Migration in the Mediterranean", Mediterranean Politics, 11, no. 1 (2006): 59-82.

Ministerios de Asuntos Exteriores. "La crisis de Canarias es fruto del éxito de la nueva relación con Marruecos". http://www.mae.es.

Ministerio de Asuntos Exteriores y de Cooperación. Plan África: 2006-2008 Resumen Ejecutivo. Madrid, May 2005. http://www.mae.es/es/Home/planafrica.htm.

Ministero dell'Interno. Comunicazione del Ministro dell'Interno al Senato della Repubblica, Seduta di mercoledì 29 giugno 2005. http://www.interno.it/sezioni/ministro/ intervistadiscorso.php?idarticolo=360\#top.

Moroccan Ministry of Foreign Affairs. "Speeches, Declarations, and Interviews". http:// www.maec.gov.ma/EN/l-com.asp?typ = else.

Mrabet, E. A. "Readmission agreements: The Case of Morocco", European Journal of Migration and Law, 5 (2003): 379-85. 
Nascimbene, B. "Relazioni esterne e accordi di riammissione". In Le relazioni esterne dell'Unione Europea nel nuovo millennio, edited by L. Daniele, 291-310, Milano: Giuffrè editore, 2001.

Resmann, F. "Immigration Management in Spain: A Case Study of the Immigration Management Politics at the National Spanish and European Union Levels". PhD diss., Lund University, 2006. http://theses.lub.lu.se/archive/2006/05/23/1148375158-19331-777/ Immigration_management_in_Spain_pdf.pdf.

Schieffer, M. "Community Readmission Agreements with Third Countries - Objectives, Substance and Current State of Negotiations", European Journal of Migration and Law, 5, no. 3 (2003): 343-57. 